\title{
CORRECTION
}

\section{Correction: Infection of urinary tract in menopausal women}

(Vol 14, No 2, p. 203-208, 2019)

Ispravka: Infekcije urinarnog trakta kod žena u menopauzi

(Vol 14, No 2, p. 203-208, 2019)

\author{
Smieško Gordana ${ }^{12}$ \\ ${ }^{1}$ Institute of Public Health of Vojvodina,Novi Sad, Serbia \\ ${ }^{2}$ Department of Microbiology, Faculty of Medicine Novi Sad, University of Novi Sad, Serbia
}

The Editorial Board of "Sanamed" journal, in agreement with author (Smjesko Gordana) of the paper "Infection of urinary tract in menopausal women (Vol 14, No 2, p. 203-208, 2019) who pointed out the technical errors that occurred after the paper was published, made the decision to do the necessary corrections in accordance with the prescribed procedure. We apologize the author for errors that occurred in published paper and thank her for assistance in detecting them. According to that, the appropriate correction was made.

The following updates were made:

a) Under the title of the paper on page 203, instead of Smieško Gordana ${ }^{12}$ shoud stand Smieško Gordana

b) Under the authors name on page 203, instead ${ }^{1}$ Institute of Public Health of Vojvodina, Novi Sad,
Serbia and ${ }^{2}$ Department of Microbiology, Faculty of Medicine Novi Sad, University of Novi Sad, Serbia shoud stand University of Novi Sad, Medical Faculty, Institute of Public Health of Vojvodina, Novi Sad, Serbia.

c) In the section "Sažetak" on page 207, under serbian translation of the title of the paper instead of Smieško Gordana ${ }^{12}$ shoud stand Smieško Gordana.

d) In the section "Sažetak" on page 207, under the name of the author, instead ${ }^{1}$ Institute of Public Health of Vojvodina, Novi Sad, Serbia and ${ }^{2}$ Department of Microbiology, Faculty of Medicine Novi Sad, University of Novi Sad, Serbia shoud stand University of Novi Sad, Medical Faculty, Institute of Public Health of Vojvodina, Novi Sad, Serbia 